Greengard

Le of And Twig Characters Of Certain Varieties of Apple 



\section{LEAF AND TWIG CHARACTERS}

OF

CERTAIN VARIETIES OF APPLE.

BY

LOUIS JACOB GREENGARD

\section{THESIS}

FOR THE

DEGREE OF BACHELOR OF SCIENCE

IN

AGRICULTURE

COLLEGE OF AGRICULTURE

UNIVERSITY OF ILLINOIS

1916 



\section{6 \\ $483 \frac{1}{9}$ \\ $\stackrel{\circ}{\circ}$}

UNIVERSITY OF ILLINOIS

Sxay 30. 1966

THIS IS TO CERTIFY THAT THE THESIS PREPARED UNDER MY SUPERVISION BY Louis Jacob Greengard

ENTITLED - Leaf and Twig Characters of Certain Varieties of Apple.

IS APPROVED BY ME AS FULFILLING THIS PART OF THE REQUIREMENTS FOR THE DEGREE OF Bachelor of Science in Agriculture.

APPROVED:

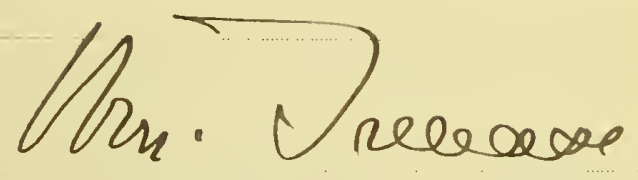

Instructor in Charge

HEAD OF DEPARTMENT OF

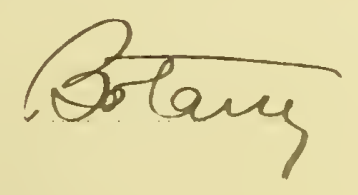





\section{ACKNOWIEDGMENTS}

I wish to express my great indebtedness and thanks to Professor William Trelease, under whose supervision this thesis has been prepared, and by whose helpful criticism and judgment

I have so greatly profited. My earnest thanks are Iikewise due to Professor C. S. Crandall for many valuable suggestions, and for permission to gather material from the trees in the University orchards. I have also to acknowledge the co-operation of Mr. R. L. Davis who had associated himself with me when my problem was first undertaken, but who has subsequentIy devoted himself to a monographic treatment of the species of the Genus Malus. 
Digitized by the Internet. Archive in 2013 
TABLI OF CONTENTS.

Page

I Introduction

II A Key to the Apple Varieties Described

III Description of Varieties

IV Bibliography

41

Alphabetical Index
9

2

7

42 



\section{LEAF AND TWIG CHARACTERS OF SONE VARIETIES OF APPLE}

$$
\text { I. }
$$

Introduction.

An attempt has been made in the following pages to differentiate between a few varieties of apple by using characters other than the well-know standard descriptions of fruit, which have always served to distinguish them. The advantage of distinguishing varieties without recourse to fruit is of very great service as a means of determining the true name of an apple tree that has not yet come into bearing. At the outset of my work I was led to believe that a study of the morphology of the autumnal leaves and of the twigs in late winter might reveal variations as diverse and of as great a taxonomic value as the characters which have been found in the fruit. That the differences which were found in the few varleties treated here, although minute in the majority of cases, are quite definitely discernable and fairly constant, can, I think, be seen from the descriptions themselves or from the key, which is based upon them. With a representation of only some 21 varieties out of a list of 1856 as given by the Downings in 1845 and $1869 \%$, the work can have no pretensions to being more than a beginning to a treatment of the subject from the new point of view that has *Page 15. 

been suggested. Since I could not hope to exhaust the material available, I was moved to present what I have done in the hope that it would serve as an illustration of the feasibility of describing apple varieties without recourse to fruit characters, and that more can be added to it in the future.

For such varieties as it does contain, I believe the key holds good, although it is, of course, subject to weakness by the fluctuating variations induced in the specimens of the varieties treated, by differences in clinate and character of the season, although the fruit itself is not more free from these fluctuations due to seasonal and other environmental changes than are the characters that I have used.

Two collections of material were made; the first in the early part of October, 1914; when terminal shoots of non-fruiting branches were cut from the trees in the Orchard of the Illinois Agricultural Experiment Station. These leafy twigs were dried under pressure between sheets of absorbent paper, according to the usual practice, and form the basis for the descriptions of fall leaves and the key. The second collection was made in the latter part of February and the beginning of March, 1915; straight vegetative growths from the north side of the tree free from fruit spurs being chosen wherever possible. The securing of such vegetative twigs was easy in the case of trees that had not come into bearing, but in the case of some of the older specimens it was impossible to avold incluaing some fruiting wood but the collections was then supplemented by the addition of a watersprout when such was available. The twigs were not subjected to any pressure but were simply tied in 

bundles of convenient size and exposed on the shelf in the laboratory where they were soon dried out by the air.

In writing up the descriptions, the first step was to eliminate synonymy and establish the correct name for the specimen. In this I was guided by Beach's work, The Apples of New York, cited in the bibliography as 1 and 2 and by 7 . H. Ragan's work, Nomenclature of the Apple, published as Bulletin 56 of the Bureau of Plant Industry, United States Department of Agriculture, and cited in the Bibliography as 3. In addition to the synonymy a statement as to the season of maturity of the fruits and something as to its place of origin, is made from the sources 1, 2, and 3, and Beach's observations on the habit of growth of the tree are quoted before the description of leaves and twigs based on my own observation, is given. It has been my aim as far as possible to employ descriptive words and phrases in their ordinary meaning as used by the taxonomist, but the fact that I attach significance to much finer distinctions than are used in writing the ordinary species description may have led to obscurity in some cases, which I hope to clear up as far as possible in this introductory discussion. For convenience I have divided the leaf into three parts, the lamina or blade, the petiole, and the stipules. The word "lamina" is used for the blade consistently throughout the key, but in the descriptions the term does not appear, the word "leaves" being used to denote it for the sake of simplicity of diction, since there can be no doubt as to what is meant. The stipule, even though it is an integral part of the leaf, ${ }^{6}$ is treated separately, since it presents so much diversity of form 

and development that it is of the highest taxonomic value. The term petiolate is applied to stipules having the lower portion constricted to resemble a petiole, according to De Candolle. 5 For the contrasting character, namely, with no constriction of the lower portion, the term "sessile" is used, since it may be used with propriety to signify the condition of an organ which may be stalked but happens not to be stalked in the case under consideration. 5

In the character of the winter twigs there appears to be some uncertainty among writers as to just what is meant by the term scarfskin, whether it is to be taken as a flaking of $f$ of the epidermis, or whether it is the waxy coating which sometimes appears on the bark in more or less sheltered placés, 4 to avoid ambigulty I have in all cases considered the scarfshin to be a flaking off of the epidermis and have described it as such, since it appears to be the condition that prevails, and have mentioned the waxy bloom separately in such specimens as show 1t. The term "arcuate" as applied to leaf-scars calls for some elucidation, perhaps. By the word "arcuate", I mean that the scar is shaped like a bow, that is, its upper margin is simply curved and the lower margin curves downward in the center to form a small, yet rather evident lobe. The term "sinus" also is used in the work in somewhat an unusual connection. A sinus is properly the bay between lobes of a lobed leaf, but since these laminae are not lobed, but variously toothed, I have used the word to indicate the interstices between teeth, believing that it was not stretching the meaning too far in a case where none of the specimens are lobed. 

Sources are cited throughout the text by the numbers which correspond to the works as numbered in the Bibliography at the end of the paper. The stipules shown in the plate were photographed on a scale of three times their natural size, using daylight exposure and prints were made on the ordinary glossy or "bromide" paper. 

II.

A Key to the Apple Varieties Described*

1. Stipules absent, very rare, or stipules vestigial. 2

1. Stipules present and well developed. 4

2. Base of lamina cuneate.

2. Base of lamina round or slightly cordate.

Early Ripe p.16

3. Petiole tomentose throughout especially near the pulvinus: stipules not infrequent, vestigial, i.e. not over $2 \mathrm{~mm}$. long. $\quad$ Yellow Transparent p.39

3. Petiole glabrous beneath: stipules very rare but when found reaching $6 \mathrm{~mm}$. in length. Minkler p.27

4. Base of lamina cuneate. 5

4. Base of lamina round or more or less cordate. 10

5. Margin of lamina serrate. 6

5. Margin of lamina biserrate. 7

6. Margin of lamina serrulate, teeth rather widely spaced, with

6. Nargin of lamina finely crenate-serrate; apex of $\frac{\text { Willow }}{\text { teeth }}$ obtuse. Early Harvest p. 15

6. Margin of lamina serrate of biserrate; the teeth rather broader than deep, curving well forward, points roundish blunt. Winesap p. 36

7. Primary teeth with sharp beak; sinuses acute, narrow or medium in width. 8

7. Primary teeth obtusely pointed. 9

8. Leaves characteristically twisted and drooping; stipules linear, sessile.

Dornine p. 13

8. Leaves straight, i.e. neither twisted nor drooping: stipules lanceolate-iinear, long petiolate. Grimes p. 21

8. Leaves straight, i.e. neither twisted nor drooping, lamina broadly ovate, stipules lanceolate, short petiolate, their margins sinuately dentate.

Wythe p. 38

8. Lamina long ovate acute, approaching lanceolate especially on terminal leaves: margin of stipules sinuate dentate.

9. Lamina mostly lanceolate ovate but occasionally Jonathan p. 24 stipules linear acicular acuminate somewhat petiolate the margin slightly undulate with vestiges of a few spinelike teeth.

Winesap p. 36

*According to the character of the foliage in the month of October. 

9. Lamina ovate or occasionally elliptic-oblong: stipules long slender petiolate, serration of their margins like that of the Iamina.

Osceola p. 30

10. Stipules linear, awl shaped, or lancelate-linear. Il

10. Stipules lanceolate. 12

11. Stipules lanceolate-linear, acute falcate; the margin entire. $\quad$ Baldwin p. 10

11. Stipules linear, acute, not falcate, petiolate, the margin undulate and edged with a few dark spine-like glands.

Arkansas p. 9

11. Stipules mostly found on basal leaves, linear, acute, petiolate, the margin rather prominently toothed near the base, but the serration becoming reduced to undulations near the apex: small leaves as a rule glabrescent and the largest leaves glabrous irrespective of age. Northwestern p. 28

11. Stipules awl-shaped, long curving acuminate, sessile, with lower portion rather markedly thickened. Garfield p. 19

12. Stipules long and slender petiolate; serration of their margins like that of the lamina: lamina ovate or occasionally elliptic oblong.

Osceola p. 30

12. Stipules with base tapering to very short petiolate, or short petiolate. 13

12. Margin of stipules, entire or very rarely with one or two projecting teeth: lamina roundish ovate. McIntosh p. 25

13. Margin of stipules undulate or occasionally undulate and spiny toothed. 14

14. Lamina broadly lanceolate: stipules rather abundant and of ten attaining large size; petiole tomentose throughout; with narrow, shallow, and inconspicuous groove.

14. Lamina long elliptical but occasionally oved Astrachan p. 32 stout; groove narrow; sparsely tomentose above, more densely so at the base; glabrous beneath.

Famuese p. 18

14. Lamina ovate, apex acute: leaves somewhat curving and drooping along the midrib: petiole slender, groove rather narrow and very shallow: tomentose.

Isham p. 22 



\section{III.}

Description of Varieties.

ARRANSAS.

Synonyms: Black Twig, Mammoth Black Twig. "This is doubtless Arkansas. " 3

Late variety originated in Arkansas from a seedling. Winesap group. ${ }^{1}$

"Tree rather large, vigorous, branches large, crooked, stout. Form upright, spreading, rather open,"I

Leaves ovate, abruptly acuminate, base very slightly cordate; rather deeply serrate, the teeth broad and suddenly tapering to a long sharp point; sinuses rather narrow, acute; glabrous above except for a tomentura which is more or less dense on the midrib and occasionally extends sparsely to the principal veins; glands very numerous, conspicuous under a lens and scattered over the entire surface; sparsely but rather uniformly tomentose beneath, reaching 8.5 by $4.6 \mathrm{~cm}$. on terminal shoots but averaging 6.5 by $3.5 \mathrm{~cm}$. lower down the twig. Petiole with very narrow and shallow groove, densely tomentose along the groove above, and on both surfaces at the pulvinus, glabrous on the upper portion beneath; $30 \mathrm{~mm}$. long, $1.5 \mathrm{~mm}$. in diameter. Stipules linear, acute, petiolate, the margin undulate and edged With a few dark, spiny glands; slightly pubescent above, densely tomentose beneath; $9 \mathrm{~mm}$. long when fully developed, $0.76 \mathrm{~mm}$. in the widest part, $0.25 \mathrm{~mm}$. wide at base.

Twigs curving, dark reddish brown, slighty pubescent through- 

out but especially so near the tips; $4 \mathrm{~mm}$. In diameter in the center of two-year old growth, tapering to $2.5 \mathrm{~mm}$. in the center of the terninal growth, mottled with dense gray scarfikin ${ }^{4}$ caused by the flaking off of epidermis; internodes usually 7 on each year's growth, infrequently 6 or 8 , 12 to $25 \mathrm{~mm}$. Iong; lenticels many, very conspicuous, scattered, round or round oval, yellowish, raised, medium in size. Terminal bua brown, oval, very obtuse; the outermost pair of bud scales extending only $5 / 6$ the total length of bud; densely tomentose; $4 \mathrm{~mm}$. In the widest part, $3 \mathrm{~mm}$. wide at base, $6 \mathrm{~mm}$. long. Lateral buds tightIy appressed on the upper portion of the shoot, free lower down; medium to large, flattened conic, acutely pointed above, obtuse lower down; $2 \mathrm{~mm}$. broad, $3 \mathrm{~mm}$. long. Leaf-scars narrow, $3 \mathrm{~mm}$. wide, $0.5 \mathrm{~mm}$. high, slightly curved, the margin fringed with hairs; bundle scars present but inconspicuous.

\section{BALDW IN .}

Synonyms: Baldwin Rosenapfel, Baldwin's Rother Pippin, Calville Butter, Felch, Late Baldwin, Pecker, Red Baldwin Pippin, Steele's Red Winter, Woodpecker. 1 Butters, Red Graft. 3

Late variety originated in Massachusetts. 3

"Tree large, very vigorous, branches large, strong. Form upright spreading, eventually becoming rather round and somewhat dense." 1

Leaves rather broadly ovate, apex acute, or with a small wedge-shaped tip, base cordate; rather deeply biserrate, the primary teeth once or twice as broad as deep, secondary teeth rather shallow incisions in the prinaries, acute pointed, sinuses 

acute, rather deep, medium in width; tomentose on the lower portion of the midrib and principal veins but otherwise glabrous above, densely tomentose beneath, becoming somewhat less so with age; usually $7.5 \mathrm{~cm}$. long $5.5 \mathrm{~cm}$. wide, seldom much smaller. Petiole stout, groove very narrow, shallow, and Inconspicuous; densely tomentose throughout or ocassionally glabrescent beneath, $20 \mathrm{~mm}$. long $2 \mathrm{~mm}$. in dlameter. Stipules present on all leaves and well developed, lanceolate-iinear, acute falcate; the marg in entire; very densely tomentose, more sparsely tomentose above; $13 \mathrm{~mm}$. long $2.2 \mathrm{~mm}$. in the widest part $0.43 \mathrm{~mm}$. at base. Twigs straight, dark red-brown, very densely pubescent at tips, and much less so to glabrate lower down; $4 \mathrm{~mm}$. In diameter at the middle of terminal growth, $6 \mathrm{~mm}$. on wood one year older; traces of thin scarfskin; internodes usually 20 to 22 on a year's growth, averaging $23 \mathrm{~mm}$. long, minimum $10 \mathrm{~mm}$., maximum $34 \mathrm{~mm}$.; lenticels many, very consplcuous, scattered, oval, yellowish, raised, medium to large. Terminal bud gray, long conic, acute, completely enfolded by the heavily pubescent dark gray outer scales; $6 \mathrm{~mm}$. long, $4 \mathrm{~mm}$. wide at base. Lateral buds free on the lower portion of the twig, partly free or slightly appressed on the tips of twigs, much flattened, broad obtuse or roundly acute pointed, base roundish, $3 \mathrm{~mm}$. broad, $3 \mathrm{~mm}$. long. Leaf-scars rather narrow arcuate, broad in the center, but with no defined lobe; $4 \mathrm{~mm}$. wide, $1 \mathrm{~mm}$. high; bundle scars small, moderately conspicuous. 

BENONI.

Synonyms: none.

Early varlety originated in Nassachusetts. 3

"Tree rather large, vigorous. Form erect to somewhat roundish, dense."

Leaves ovate, or occasionally obovate, apex abruptly acuminate, the point very small and sharp, base cuneate; serrulate, the teeth considerably broader than deep, with longish acute points curving well forward; sinuses acute, narrow; completely glabrous above in most cades, rarely with a few hairs on the lower portion of the midrib, glands rather numerous, inconspicuous, mostly in the region of the principal veins; glabrescent to glabrous beneath, the hairs (when found) persisting along the midrib and veins; $7.5 \mathrm{~cm}$. long, $3.5 \mathrm{~cm}$. wide. Petiole rather slender, groove wide, shallow, sparsely tomentose above, glabrous beneath except at the pulvinus which is heavily tomentose; $30 \mathrm{~mm}$. Iong, $1 \mathrm{~mm}$. in diameter. Stipules well developed and abundant, most fully developed on the smaller leaves where they are lanceolate, acuminate, distinctly petiolate, the margin undulate and toothed with a dark spine, pinnately veined, the midvein and secondaries rather prominent; glabrous above except near the base which is sparsely tomentose; glabrous beneath except for a sparse fringe of marginal hairs; $9 \mathrm{~mm}$. Iong, 1.36 $\mathrm{mm}$. In the widest part $0.25 \mathrm{~mm}$. wide at the base.

Twigs rather long, fairly straight and slender, light olive green and well covered with gray scarfskin, densely pubescent at tips, becoming less so lower down; $2 \mathrm{~mm}$. In diameter at the center of terminal growth, $3 \mathrm{~mm}$. on growth of the year before; 

internodes 7 to 10 on each season's growth, 20 to $30 \mathrm{~mm}$. long, usually $25 \mathrm{~mm}$; lenticels rather numerous, consplcuous, elongated oval, light yellow, slightly raised, medium in size. Terminal bud long conic, obtusely pointed, completely covered with very heavily pubescent scales, $3 \mathrm{~mm}$. Wide at base, $5 \mathrm{~mm}$. Iong. Lateral buds small, tightly appressed, obtuse, blunt pointed, pubescent, $2 \mathrm{~mm}$. broad, $1.5 \mathrm{~mm}$. long. Leaf-scars curved, medium in width, $2 \mathrm{~mm}$. broad, $1 \mathrm{~mm}$. high, with 3 conspicuous, nearly round, raised, bundle scars.

DOMINE.

Synonyms: American Nonpareil, Cheat, Eling Tight, Domini, Dominie, English Beauty, English Rambo of some, English Red Streak, Hogan, Red Streak, Striped Domine Pippin, Striped Rhode Island Greening, Wells, Wells of OhIo, Williamson, Winter Rambo of some, 3 Ramboulrette.

Late variety of uncertain origin, but supposedly American, ${ }^{1}$ related to Rambo. 1

"Tree very vigorous to moderate vigorous, 'with long, stout, spreading branches which are very likely to be broken by the heavy crops of frult (Iyon - Michigan Hort. Soc. Rpt. 1890 page 290). Form upright spreading.' Mith a straggling, open head bearing its fruit crowded along the smaller branches. (Warder American Pomology, Apples, 1867 page $430 \mathrm{f} 1 \mathrm{~g}.) . " 1$

Leaves elongated oblong ovate, the apex acute, base cuneate, drooping and characteristically twisted, rather deeply biserrate, the primary teeth with a sharp beak, sinuses acute, narrow; glabrous above except for a very slight tomentum on the midrib, 

glabrescent beneath, the few scattered halrs confined to the midrib, and principal veins, $8.5 \mathrm{~cm}$. long, $4 \mathrm{~cm}$. wide. Petiole tomentose in the groove above, sparsely hairy boneath, $35 \mathrm{~mm}$. long, $1.5 \mathrm{~mm}$. wide. Stipules linear acute, pilose at.base, glabrous above, sparcely hairy beneath, the margin edged with very sharp spiny teeth one of which points the apex, $5 \mathrm{~mm}$. long, $0.5 \mathrm{~mm}$. wide.

Twigs very straight and rather stout, rather dark red-brown, pubescent throughout but more puberulent than pubescent on the older portion; $2.5 \mathrm{~mm}$. in dlameter at the center of the terminal growth, $4.5 \mathrm{~mm}$. on the previous year's wood, epidermis minutely flaked to form a uniform thin scarfskin, no waxy bloom; internodes 7 on each season's growth, 8 to $20 \mathrm{~mm}$. long on terminal growth, averaging $15 \mathrm{~mm} ., 25$ to $50 \mathrm{~mm}$. long on the older portion; lenticels not numerous, inconspicuous, especially clustered around the nodes, roundish oval, slightly raised, light yellow on young growth, darker lower down, small. Terminal bud plump, ovate, acutely pointed, the outermost scales extending $2 / 3$ the total length of bud, densely tomentose throughout, $8 \mathrm{~mm}$. long, $5 \mathrm{~mm}$. in the widest part, $3.5 \mathrm{~mm}$. at base. Lateral buds nearly free, medium to rather large, obtusely conic, sharp pointed, somewhat flattened, sparsely tomentose at base and tip, $2 \mathrm{~mm}$. wide, $3 \mathrm{~mm}$. long. Leaf-scars narrow $2.5 \mathrm{~mm}$. broad, $1 \mathrm{~mm}$. high, crescent shaped, with one prominent central lobe; bundle scars present but inconspicuous. 

EARIY HARVEST .

Synonyms: Early French Reinette, Early July Pippin, Early June, Harvest, July Early Pippin, July Pippin, Large Early, Large Early Harvest, Large White Juneating, Maralandica, Pomme d' Ete of Canada, Prince's Early Harvest, Prince's Harvest, Frince's Yellow Harvest, Yellow Juneating. ${ }^{2}$ Brocken, Glass Apple, Harvest Early, Large Yellow Harvest, Princess' Harvest, Simlay's Yellow: Medium early varlety originated in America. ${ }^{3}$ Origin unknown but suposedly American.2

"Tree medium size, moderately vigorous. Form upright spreading, roundish, open." 2

Leaves broadly ovate, apex acute, base cuneate (not cordate), finely crenate-serrate, the teeth very broad, not deep ( 3 to 4 times as broad as deep), their apices obtuse, sinuses acute, very narrow and shallow; tomentose on the lower portion of the midrib and at the base of the primary veins, but otherwise glabrous above; entirely glabrous beneath, except for a slight tomentum along the midrib and veins which often persists on the very oldest leaves; $7.5 \mathrm{~cm}$. long, $5 \mathrm{~cm}$. broad and seldom varying from these dimensions. Petiole stout, slightly swollen at the pulvinus, groove rather broad, shallow; densely tomentose throughout in many cases, but occasionally glabrous beneath; $20 \mathrm{~mm}$. 1ong, 2 mm. In diameter. Stipules leafy, i.e. attaining considerable size in the majority of cases, rarely reduced to acicular or linear on basal leaves and especially developed on terminal leaves where they are lanceolate, acute, petiolate, the margin shallowcrenate, with very short hairs all over the upper surface; tomentase on the "petiole" above; tomentose throughout beneath, and especially 

so on the "petiole;" maximum size $8 \mathrm{~mm}$. 10ng, $4 \mathrm{~mm}$. In the widest part, $0.8 \mathrm{~mm}$. at base, and frequently somewhat smaller.

Twigs straight, or the last $3 \mathrm{~cm}$., of growth curving upTards, dark brown mixed with olive green, rather densely pubescent in large patches throughout, 3 to $4 \mathrm{~mm}$. In the center of terminal growth 5 to $6 \mathrm{~mm}$. on wood of the year before, epidermis flaked off thinly in streaks to form a light scarfskin, internodes 18 on the year's growth, maximum length $30 \mathrm{~mm}$, minimum $6 \mathrm{~mm}$. average $19 \mathrm{~mm}$; lenticels rather few, very conspicuous, scattered, round, light yellowish, not raised or sunken, medium to large. Terminal bud broad, roundish conic, apex rather obtuse, the outermost bud scaled extending only $2 / 3$ the total length of the bud very densely tomentose, $7 \mathrm{~mm}$. In the widest part, $5 \mathrm{~mm}$, at base, $8 \mathrm{~mm}$. Iong. Lateral buds free, medium to above medium, rather plump, obtuse deltoid, apex obtuse, base roundish, tomentose on the margin of scales, $3 \mathrm{~mm}$. broad, $4 \mathrm{~mm}$. long, leaf-scars, narrow, crescent shaped, not lobed, 3 to $4 \mathrm{~mm}$. broad $0.5 \mathrm{~mm}$. high in the center; bundle scars absent, or when present very inconspicuous.

\section{EARLY RIPE.}

Syronyms : Teidner. 3

Medium early varlety, orlginated in Pennsyvania? ${ }^{3}$

"Tree large, vigorous but moderately long, stout branches. Form upright spreading, rather dense, top roundish. "2

Leaves broadly ovate, occasionally obovate, abruptly acuminate, base cuneate, quite regularly. biserrulate, the teeth somewhat longer than broad, tapering acutely and often tiped with a dark spine, sinuses acute, rather broad, the sides somewhat 

curving; glabrous above except on the midrib which is sparsely hairy throughout its length, glands numerous, rather conspicuous, scattered over the surface; very sparsely but uniformly tomentose beneath, $8.5 \mathrm{~cm}$. long, $6 \mathrm{~cm}$. wide, but frequently smaller. Petiole slender, densely tomentose above, glabrescent beneath, groove inconspicuous, $45 \mathrm{~mm}$. long, I mm. in diameter. Stipules very rare, when present short acicular acute, denticulate margined, tipped with a distinct sharp spine; densely tomentose; $1.36 \mathrm{~mm}$. Iong, $0.7 \mathrm{~mm}$. wide at base.

Twigs slightly curving, decidedly reddish brown, red in scattered places, tomentose at tips and more finely pubescent lower down; $2 \mathrm{~mm}$. in diameter on the middly portion of terminal growth, $3 \mathrm{~mm}$. on wood of the previous year, and 3.5 to $4 \mathrm{~mm}$. on wood of the second year previous; epidermis flaked to form light patches of scarfskin; internodes 4 to 5 on each year's growth, minimum length $5 \mathrm{~mm}$., average $20 \mathrm{~mm}$, maximum $35 \mathrm{~mm}$; lenticels not numerous, more abundant on nodal regions, raised, rather inconspicuous, dark brown, round, small to medium. Terminal bud reddish browr, rather long conic, acute, the outermost pair of scales extending only $2 / 3$ the length of bud; tomentose along the edges and at tips of scales the middle portion of the scales denuded and glossy; 3.5 to $4 \mathrm{~mm}$. at base, 4.5 to $5 \mathrm{~mm}$. in the widest part, $6 \mathrm{~mm}$. long. Lateral buds partly free, the lower portion appressed below medium to large long flattened conic, apex acute, pubescent at tip but otherwise glabrous and glossy; $2 \mathrm{~mm}$. broad, $2.5 \mathrm{~mm}$. long. Leaf scars rather broad, arcuate, with prominent central loke, $3 \mathrm{~mm}$. wide $1 \mathrm{~mm}$. high, bundle scars prominent, slightly raised. 

FAMEUSE.

Synonyms: Chimney Apple, De Nèige, du Marechal, La Belle Fameuse, La Fameuse, Neige, Neige Framboise de Gielen, Pomme de Neige, Pomme Fameuse, Pomme de Fameuse, Sanguineus, Snow.2 Chinney, Snow Apple, Snow Chimne.$^{3}$

Medium early variety, originated in Canada from seed brought from France. 2

"Tree vigorous with long moderately stout branches. Form upright spreading or roundish, rather dense."2

Leaves mostly long elliptical occasionally ovate, apex abruptly acuminate, base round or very slightly cordate, beserrate, the primary teeth short and broad with a rather long acute point, secondary teeth very small, tipped with a small dark spine, sinus acute, shallow, curving, glabrous above except for a tomentum on the whole length of the midrib with a few hairs occasionaliy at the base of the princlpal veins, glands rather numerous, fairly prominent, and confined principally to the borders of the large veins, rather sparsely, but quite uniformly tomentose below; 8.5 $\times 4.5 \mathrm{~cm}$. to $9.5 \times 4.0 \mathrm{~cm}$. Petiole rather stout, groove narrow, sparsely tomentose above, more densely so at the base glabrous below. Stipules mostly lanceolate, tapering down gradually from the medium to become slightly petiolate, the margin undulate and spiny toothed, glabrous above, pubescent below becoming tomentose toward the base; when fully developed $13 \mathrm{~mm}$. long, $1.3 \mathrm{~mm}$. the widest part, $0.34 \mathrm{~mm}$. Wide at base.

Twigs slightly curving, dark reddish brown, pubescent with very short hairs, $2.5 \mathrm{~mm}$. in diameter in the middle of terminal 

growth, $4.0 \mathrm{~mm}$. cn two-year old wood; epldermis uniformly flaked to form a light covering of scarfskin; internodes 4 to 5 on each season's growth, 5 to $18 \mathrm{~mm}$. long, usually $10 \mathrm{~mm}$; lenticels few in number, conspicuous, scattered, roundish oval, dark.colored, raised, small. Terminal buds dark brown, longelliptical, the outer scales long and broad but not reaching to the apex, heavily pubescent especially near their tips; $4 \mathrm{~mm}$. at the broadest part, $9 \mathrm{~mm}$. Iong. Lateral buds small, flattened, obtuse conical, pubescent, free; $1.5 \mathrm{~mm}$. broad, $1.5 \mathrm{~mm}$. 1ong. Leaf-scars rather broad crescent shaped, $2 \mathrm{~mm}$. broad, $1 \mathrm{~mm}$. high in the center; bundle scars conspicuous.

GARFIEID.

Synonyms: none.

Late American variety, origin Georgia? Illinois? for one variety of the name, Rhode Island? for the other. ${ }^{3}$ Not listed. 1

Leaves broadly ovate, acuminate or acute, tapering roundy toward the petiole, rather finely biserrate, the teeth blunt pointed, carried well forward, the margin becoming entire near the base, sinuses very narrow, deep, acute; glabrous above except for a tomentum on the midrib, the surface covered with minute transparent glands; glabrous beneath except for a very few occasional. hairs on the midrib, the surface glossy.and showing the veins prominently; $9 \mathrm{~cm}$. 1ong, $5.5 \mathrm{~cm}$. wide. Petiole slender sparsely hairy in the groove above, more densely pubescent near the pulvinus; glabrous beneath; $45 \mathrm{~mm}$. 1ong, 1.5 mm. in diameter; groove rather inconspicuous. Stipules awlshaped, tapering from a thickish base to a long curving point, 

the margin entire; tomentose beneath especially the lower twothirds; glabrous above, the uniformly pubescent appearance being caused by the rolling together of the sides toward the midrib; $4 \mathrm{~mm}$. long, $0.25 \mathrm{~mm}$. wide.

Twigs very straight, terete, light yellowish green near the tips darkening to glossy ashen-gray on the older portions, epidermis showing as thick large patches of gray scarfskin; bark glabrous throughout except on the last node or two where it becomes pubescent and densely tomentose just below the terminal bud; $6 \mathrm{~mm}$. in diameter at the center of 4 year-old growth, $4 \mathrm{~mm}$. at 1 year old wood, and $3 \mathrm{~mm}$. in the center of the terminal shoot. Watersprouts branching freely the first year, $6 \mathrm{~mm}$. at base, 2.5 mm. at tip; internodes very short, the nodes crowded closely together on fruiting wood; 30 to $50 \mathrm{~mm}$. apart on watersprouts; lenticels rather numerous, conspicuous, scattered, round, light yellow, raised. Terminal bud ovate conic, somewhat flattened in one direction, acute round pointed, outer scales densely tomentose and reaching only half-way to the tip, the inner pair of scales more densely tomentose than the outer pair; $4 \mathrm{~mm}$. Wide at base, $5 \mathrm{~mm}$. long. Lateral buds medium in size, broad, plump, obtusely conic, the lower half appressed, the upper portion free; sparingly pubescent near the tip; $2 \mathrm{~mm}$. wide at base, $2.5 \mathrm{~mm}$. long. Leaf-scars narrow, nearly straight, $3 \mathrm{~mm}$. wide, $0.5 \mathrm{~mm}$. high; bunde scars prominent and in a stralght line. 

GR IMES .

Synonyms: Grimes Golden, Grimes' Golden, Grimes Golden Pippin, Grime's Golden. 3

Medium late variety, 3 originated in West Virginia. 1 and 3 "Tree moderately vigorous, branches short stout, curved, crooked. Form upright spreading, or roundish, inclined to droop; rather dense." I

Leaves mostly lance-ovate, rarely ohovate, apex acute or rarely abruptly acuminate, base cuneate, not cordate; the margin rather deeply and coarsely biserrate, the primary teeth somewhat broader than long, their apices and those of the secondary teeth sharp and pointing well forward; sinuses acute, medium in width; glabrous above except for a very slight tomentum on the lower quarter of the midrib, glands very few and inconspicuous; completely glabrous to very sparsely tomentosc beneath on the oldest (basal) leaves, but quite persistently hairy on the leaves near the tips; mean size $6.5 \mathrm{~cm}$. Iong, $3.3 \mathrm{~cm}$. wide, frequently smaller and occasionally larger up to $9 \mathrm{~cm}$. by $5 \mathrm{~cm}$. Petiole rather slender, somewhat expanded at the pulvinus, groove shallow, moderately wide; tomentose in the groove and along its edges but otherwise glabrous; $30 \mathrm{~mm}$. 1ong, $1.5 \mathrm{~mm}$. in diameter. Stipules fairly numerous, rather large and well developed, lanceolate-linear, acute, long pet1olate, the margin undulate; sparsely pubescent above, densely tomentose beneath especially on the lower half along the midnerve, "petiole" comprising about half the length of stipule; $15 \mathrm{~mm}$ long when full grown, frequently smaller and averaging about $9 \mathrm{~mm}$., $1.64 \mathrm{~mm}$. In the 

widest part, $0.61 \mathrm{~mm}$. at base.

Twigs straight, dull reddish brown, pubescent at tips, glabrescent to glabrous lower down; 3 to $4 \mathrm{~mm}$. in diameter at the center of terminal growth, $5 \mathrm{~mm}$. on wood a year older, epidermis flaking in smallpatches to form a scarfskin; internodes 18 to 19 on each year's growth, rather short, averaging 17 mm., minimum $8 \mathrm{~mm} ., \operatorname{maximum} 25 \mathrm{~mm}$. in length; lenticels fairly numerous, rather inconsplcuous, scattered, oval or round oval, isabelline or pale yellow, not raised or sunken, medium to small Terminal bud long conic, apex truncate, the outer scales completely enfolding it; densely tomentose, $4 \mathrm{~mm}$, at base, $5.5 \mathrm{~mm}$. long. Lateral buds free, or rarely appressed for $1 / 3$ their length, medium in size, flattened long conic, apex obtuse, denseIy hairy on the inner scales, the outermost scales glabrous except at tip and edges; $3 \mathrm{~mm}$. at base, $4 \mathrm{~mm}$. 1ong. Leaf-scars narrow crescent shape, with no marked central lobe, 3 mm. broad, $1 \mathrm{~mm}$. or less high; bundle scars small and inconspicuous.

\section{ISHAM}

Synonyms: Isham sweet. 2 and 3

Niedium late variety originated in Wisconsin. 3 From seed of Bailey Sweet. 2

"Tree moderately vigorous. Form upright spreading." 2

Leaves somewhat curving or drooping along the midrib, ovate acute, the base slightly cordate; biserrate or simply serrate, teeth slightly broader than deep, acuminate; sinuses acute; tomentose on, and adjacent to, the midrib and on the principal veins above, glands very numerous and consplcuous; glabrate 

beneath, the hairs persisting along the midrib and veins; 8.8 cm. long, $4.3 \mathrm{~cm}$. wide. Petiole slender, groove rather narrow, very shallow, tomentose, $30 \mathrm{~mm}$. Iong, $1 \mathrm{~mm}$. In diameter. Stipules lanceolate acute, undulate and toothed with minute spinelike glands; glabrous above, somevhat pubescent beneath, $9 \mathrm{~mm}$. Iong, $1.02 \mathrm{~mm}$. in the widest part, $0.26 \mathrm{~mm}$. wide at base. Twigs bearing fruit spurs much curved and irregularly twisted, watersprouts and those carrying no fruit-spurs straight or nearly so, red brown, rather tomentose on terminal shoots, becoming nearly glabrous lower down, and completely glabrous on older fruiting twigs; $4 \mathrm{~mm}$. in dameter at the center of twoyear old wood, 3 to $3.5 \mathrm{~mm}$, at the center of terminal growth; epidermis roughened to produce a thick scarfskin, patches of dull grayish bloom in sheltered places on old fruiting wood; internodes 6 to 7 on each season's growth, mostly $30 \mathrm{~mm}$. in length on vegetative shoots, but ranging from 12 to $35 \mathrm{~mm}$ : lentice Is fairly numerous, conspicuous, scattered, usually long elliptical but occasionally nearly round, light yellow, not ralsed or sunken, rather large. Terminal bud obtusely conic, truncate, completely enveloped by the outer pair of scales; densely tomentose throughout, 4 to $5 \mathrm{~mm}$. long, $4 \mathrm{~mm}$. wide at base. Lateral buds rather large, broad and much flattened, cuneiform, round pointed, appressed so tightly to the bark as to be slightly sunken; densely tomentose throughout; $3 \mathrm{~mm}$ wide at base, $3 \mathrm{~mm}$. long. Leaf-scars curved, very narrow; $4 \mathrm{~mm}$. in width, heavily pubescent, bundle scars very evident and raised. 

JONATHAN .

Synonyms: Esopus Spitzenburg (New), Johnathan, Philip Rick, King Philip, Ulster Seedling, Winesap (erroneously), Wine (erroneously), 1 New Spitzenburgh. 3

Late variety, originated from a seedling of Esopus, on the farm of Mr. Philip Rick, Ulster County, New York. 1

"Tree medium in size, a moderately vigorous or rather slow grower. Form roundish or spreading, sorewhat drooping, rather dense." I

Leaves long ovate, approaching the lanceolate especially on terminals, apex acute, base cuneate, not cordate; biserrate, the teeth rather blunt and rounding, broad and pointing forward; sinuses acute; tomentose along the entire midrib and primary veins above, but otherwise glabrous; densely and uniformly, tomentose beneath; $6.5 \mathrm{~cm}$. long, $2.5 \mathrm{~cm}$. wide, on terminals 7 by $4 \mathrm{~cm}$. lower dom. Petiole tomentose on the lower surface on terminal leaves; glabrous with age except at the pulvinus, pubescent in the groove above, groove well marked; 20 to $25 \mathrm{~mm}$. long, $1.5 \mathrm{~mm}$. In diameter. Stipules lanceolate Iinear, apex acute, base narrowing to the petiolate condition, 5 sinuate dentate; glabrous above, tomentose beneath; averaging $15 \mathrm{~mm}$. long, $2 \mathrm{~mm}$. in the widest part, $1 \mathrm{~mm}$. at base; often smaller, infrequently reaching $15 \mathrm{~mm}$. in length and $4 \mathrm{~mm}$. In width.

Twigs somewhat curving, mostly reddish brown but green in places, densely tomentose on terminal shoots but completely glabrous on older wood; $3 \mathrm{~mm}$. in diameter at the center of terminal growth, $4 \mathrm{~mm}$. at the center of wood one year older; 

epidermis uniformly flaked to form a scarfskin; internodes 9 to 13 on each year's growth mostly 20 to $30 \mathrm{~mm}$. Iong, frequently shorter, selaom longer; lenticels rather few, conspicuous, very scattered, long oval, light green, not raised or sunken, rather large. Terminal bud ovate to nearly globose, not pointed, denseIy tomentose throughout, the outermost pair of scales extending nearly to the apex, $5 \mathrm{~mm}$. long, $4 \mathrm{~mm}$. in the broadest part, 3 $\mathrm{mm}$. at base. Lateral buds large, free, much flattened very obtusely conical; tomentose throughout; $3 \mathrm{~mm}$. wide at base, 4.5 mm. long. Leaf-scars curved, narrow, $4 \mathrm{~mm}$. wide, I mm. high; densely pubescent on the top portion becorning less so lower down; bundle scars small and inconspicuous.

\section{INTOSH.}

Synonyms: MC Intosh Red. 2 and 3

Medium late variety originated in Ontar $10^{3}$; of the Fameuse group. 2

"Tree vigorous with numerous small slender laterals. Form roundish or spreading." 2

Leaves roundish ovate, acute or slightly acuninate, base rather deeply cordate, medium to finely biserrate, the primary teeth rather broader than long, very sharp pointed, secondary teeth reduced to slight inclsions in the margin; sinuses shallow, acute; glabrous except for a slight tomentum on the lower portion of the midrib above; with rather numerous glands bordering the primary veins; very sparsely tomentose along the edges of the veirs beneath; reaching 8.5 by $7 \mathrm{~mm}$. In size at the basal portion, averaging 7 by $6 \mathrm{~cm}$. and frequently smaller. Petiole 

rather stout, not much expanded at the pulvinus, groove very narrow, shallow and inconsplcuous; very densely tomentose along the edges of the groove, but otherwise glabrous; $26 \mathrm{~mm}$. Iong, $1.5 \mathrm{~mm}$. to $2 \mathrm{~mm}$. in diameter. Stipules abundant, i.e. persistent on terminal and lateral leaves, lanceolate acute, short petiolate, the rargin entire or very rarely with one or two small projecting teeth; glabrous above, densely tomentose beneath and especially so at base; $5.65 \mathrm{~mm}$. Iong, 1.04 m. im the widest part, $0.54 \mathrm{~mm}$, at the base.

Twigs straight, brilliant deep red-brown, sparsely pubescent with very short hairs; 3.5 to $4 \mathrm{~mm}$. in diameter in the center of terminal growth, 4 to $6 \mathrm{~mm}$. on wood one year older, internodes 12 on each jear's growth, averaging $19 \mathrm{~mm}$. Iong, maximum length $30 \mathrm{~mm}$., minimum $12 \mathrm{~mm}$; lenticels many, very consplcuous, scattered, linear-oval, whitish, raised, small. Terminal bud short cylindrical-conic, apex truncate or obtuse, the outer pair of scales reaching nearly to the tip; very densely pubescent; $5 \mathrm{~mm}$. wide, $7 \mathrm{~mm}$. long. Lateral buds tightly appressed, rather plump, broad cuneiform, apex obtusely round pointed, sparsely tomentose along the edges of the scales and especially so at tips, but otherwise denuded and glossy, bright green; medium size, $3 \mathrm{~mm}$. wide at base, $3.5 \mathrm{~mm}$. Iong. Leaf scars narrow arcuate with no we11 marked central lobe, 2.5 to $3 \mathrm{~mm}$. broad, less than $1 \mathrm{~mm}$. high; bundle scars raised and very prominent. 



\section{MINKLIR .}

1 and 3

Synonyms: Brandywine, Logan's Northern Pippin, Mumper Vandevere Late varlety originated in Pennsylvania, 3 on the farm of John Mumper near Dilisbury.

"Tree large, very vigorous, branches large and strong, forming a very broad angle with the trunk and having a characterlstically zigzag irregular manner of growth. Form very spreading, frequently becoming drooping in old trees."I

Leaves ovate, medium in breadth, apex a sharp wedge $8 \mathrm{mr}$. wide and $10 \mathrm{~mm}$. Iong, base rounding to very slightly cordate; the margin serrate, the teeth only slightly broader than deep, points sharp and inclining toward the apex; sinuses rather narrow, acute, margin of the wedge entire or nearly so; glabrous on the upper surface except for a very slight tomentum on the lower portion of the midrib, the surface thickly dotted with minute white glands conspicuous under a lens; very sparsely tomentose on the under surface of the youngest leaves, becoming nearly, if not completely, glabrous on the leaves at the basal portion of the twig; $7 \mathrm{~mm}$. long, $4 \mathrm{~mm}$. broad when fully developed on terminals, frequently smaller, and usually 2.5 by $3 \mathrm{~cm}$. on the basal portion of the twig. Petiole glabrous on both surfaces except in the groove on the lower portion which is slightly hairy; groove very narrow, shallow, and inconsplcuous. stipules rare at the end of the season (October), where present they are lirear awl-shaped, petiolate, margin slightly undulate; glabrous above, tomentose near the base beneath; $6 \mathrm{~mm}$. Iong, $0.5 \mathrm{~mm}$. broad. 

Twigs straight or only slightly curving, dull red, densely pubescent at tips, becoming much less so lower down; $4 \mathrm{~mm}$. in diameter at the center of terminal growth, 5 to $6 \mathrm{~mm}$. on wood one year older, epidermis flaking in large patches to form a grayish scarfskin; internodes 15 to 20 on one year's growth, varying greatly in length, from $35 \mathrm{~mm}$. down to $9 \mathrm{~mm}$, but usually 20 to $25 \mathrm{~mm}$.; lenticels rather numerous, conspicuous, scattered, roundish oval to oval, pale yellow or whitish, slightly raised, medium to small. Terminal bud large, plump, obtusely conic, apex blunt; densely tomentose throughout; marked with conspicuous narrow leaf-traces encircling it; the outermost pair of scales meeting at the tip; $8 \mathrm{~mm}$. 1ong, $5 \mathrm{~mm}$. wide at base. Lateral buds large somewhat flattened roundish-ovate and obtuse; broady conic and acute pointed; sparsely tomentose throughout; usually appressed for nearly the entire length, but occasionally with the upper half free; $4 \mathrm{~mm}$. 1ong, $3 \mathrm{~mm}$. wide at base, seldom smaller. Leaf-scars narrow, nearly straight, with conspicuous central lobe; $4 \mathrm{~mm}$. broad, $1 \mathrm{~mm}$. or less in height at the center; bundle scars not evident in most cases, but occasionally to be found with a lens on the older scars at the base of the shoot.

\section{NORTHWESTERN .}

Synonyms: North Test Greening, Northwestern Greening. ${ }^{1}$

Medium late variety originated in Waupaca County Tisconsin. "Tree vigorous with moderately long, stout, crooked branches. Form upright, becoming quite roundish or spreading, inclined to droop, dense."I 

Leaves rather broadly ovate, mostly acute pointed but occasionally obtuse, base tapering roundly and not cordate, the margin biserrate, primary teeth rather large and obtuse, secondary teeth brcad and very shallow incisions in the primaries; sinuses acute, about as broad as deep; at maturity absolutely glabrous above, but when younger showing a few hairs on the lower portion of the midrib; completely glabrous and glossy beneath when they have attained their maximum size, varying from very sparsely to rather densely tomentose on the smaller leaves." Maximum size $10.5 \mathrm{~cm}$. Iong, $6.5 \mathrm{~cm}$; wide; average size of smallor (slightly tomentose) leaves $7 \mathrm{~cm}$. long, $5 \mathrm{~cm}$. wide. Petiole with narrow but well marked deep groove; tomentose along the edges of the groove above, sparsely tomentose at the pulvinus beneath but otherwise glabrous; $33 \mathrm{~mm}$. long, $1.5 \mathrm{~mm}$. in diameter. Stipules mostly found on leaves at the base of shoots, Iinear, acute, petiolate, the margin cut by teeth which are pronounced near the base and approach mere undulations higher up; glabrous above, tomentose beneath especially at the base and along the margin; $0.87 \mathrm{~mm}$. in the widest part, $0.58 \mathrm{~mm}$. Wide at base, 12 $\mathrm{mm}$. long.

Twigs straight, dark reddish brown, lightly pubescent near the tips and becoming less so lower down; $3 \mathrm{~mm}$. In diameter in the center of terminal growth, $4.5 \mathrm{~mm}$. and $6 \mathrm{~mm}$. respectively on wood of the two years preceding, epidermis flaked to form

*This glabrousness of large leaves and pubescence of smaller leaves appears to be correlated with size only and not with age of leaf, for small leaves at least as old as the larger glabrous type appear tomentose in varying degrees. 

light gray patches of scarfskin; internodes usually 12 to 13 on each year's growth but varying from 8 to 15; ranging from 8 to $40 \mathrm{~mm}$. long, but usually $30 \mathrm{~mm}$. on an average; lenticels rather numerous, very consplcuous, scattered, oval, light yellow, raised, large. Terminal bud dull brown, truncate oval, the outermost bud scales reaching to the top, very densely pubescent with short woolly hairs, $5 \mathrm{~mm}$. at base, $6 \mathrm{~mm}$. long. Lateral buds entirely free, large, much flattened, cuneiform, apex acute, base slightly curved; sparsely tomentose at tips of scales and at the leaf-scars; $3 \mathrm{~mm}$. broad, $4 \mathrm{~mm}$. long. Leaf-scars narrow, arcuate; $4 \mathrm{~mm}$. Wide, $1 \mathrm{~mm}$. high at the center of lobe; bundle scars prominent.

\section{OSCEOLA.}

Synonyms: none.

Late variety originated in Indiana. ${ }^{3}$ Not listed. ${ }^{1}$

Leaves ovate or occasionally elliptical-oblong, acute or occasionally acuminate, base cuneate or very slightly cordate; the margin biserrate, the teeth very broad and shallow, apex blunted and rounding; sinuses acute; completely glabrous above except for a few hairs on the midrib near the petiole and a few shorter occasional hairs on the principal veins at their junction with the midrib, scattered groups of minute glands evident on the surface under a lens; glabrate beneath, a few hairs st111 persisting on the midrib and veins, the surface glossy; $9.5 \mathrm{~cm}$. long, $5 \mathrm{~cm}$. wide. Petiole rather stout, strict; sparsely hairy along the groove above, glabrous beneath; $25 \mathrm{~mm}$. lone, $1.5 \mathrm{~mm}$. in diameter. Stipules lanceolate, acute, serrate as are the 

leaves themselves, the marg in edged with numerous minute black spines especially abundant near the apex; glabrous above except for a few hairs on the median line; sparsely halry beneath; 17 mm. long, $2.15 \mathrm{~mm}$. in the widest part, $0.34 \mathrm{~mm}$. wide at base. Twigs straight, rather stout, dark ashen brown, densely pubescent at tips becoming less so lower down and finally glabrous on wood two years and older; 2 to $3 \mathrm{~mm}$. in dlameter at the center of terminal growth, 5 to $5.5 \mathrm{~mm}$. on wood a year older; epidermis flaking to form a dull scarfskin especially evident at nodes, with a few white waxy patches in the same sheltered places on the oldest portion, and especially on fruit spurs; internodes 3 to 4 on each year's growth, usually 4,6 to $20 \mathrm{~mm}$. long on terminal growths, usually 10 to $15 \mathrm{~cm}$. Iong lower down; lenticels not numerous, more abundant at the nodes, round, dark brown, not ralsed, rather large and conspicuous. Terminal bud long conic, acute pointed curving slightly to one side, the outermost pair of scales reaching half way to the apex; dark brown and tomentose only along the margin with the center glossy green and covered with minute, scarsely noticeable hairs, the remainIng portion of the bud densely tomentose; $10 \mathrm{~mm}$. long, $4 \mathrm{~mm}$. in the widest part, $3.5 \mathrm{~mm}$. wide at base. Lateral buds medium, obtusely conic, apex obtuse, rather flattened, only partly free; puberulent; $2 \mathrm{~mm}$. broad, $2 \mathrm{~mm}$. 1ong. Leaf-scars rather broad crescent shaped, lobe not well marked; $2 \mathrm{~mm}$. broad, $0.5 \mathrm{~mm}$. high; bundle scars distinct, rather prominently raised. 

RED ASTRACHAN.

Synonyms: Abe Lincoln, American Red, Anglesea Pippin, Astracan Rouge, Astrachan, Astrachan Red, Astrachan Rouge, Deterding's Early, Hampers American, Red Astracan, Red Astrakhan, Rother Astrakhan, Vermilion d' Ete, Water100. 2 Astrachaner Rother, Early Rus, Red Ashmore. 3

Nedium early Russian variety. 2 and 3

"Tree medium to rather large, moderately vigorous to vigorous. Form upright spreading to roundish, rather dense." 2 Leaves rather broadly lanceolate, apex acute, base somewhat cordate; the margin uniformly but not deeply biserrate, the primary teeth rather round pointed and extending well forward, secondary teeth only slight incisions in the prinaries; sinuses acute, medium in depth, and about as wide as deep; glabrous above except for a slight tomentum on the lower half of the midrib; the oldest basal leaves glabrate beneath, the hairs, in most cases sparse and confined to the principal veins; $8.5 \mathrm{~cm}$. Iong, $4 \mathrm{~cm}$. wide when full grown, but frequently much smaller, the mean size $6 \mathrm{~cm}$. by $2.5 \mathrm{~cm}$. Petiole with very narrow, shallow, and inconspicuous groove; tomentose throughout; $25 \mathrm{~mm}$. Iong, $1.5 \mathrm{~mm}$. in diameter. Stipules rather abundant, often developed to a large size, lanceolate, acute, rather short petiolate; the margin undulate or occasionally toothed; glabrous above; tomentose beneath and most densely so near the base; at maximum development $18 \mathrm{~mm}$. long, $2 \mathrm{~mm}$. in the widest part; averaging 8 to $9 \mathrm{~mm}$. Iong, $0.81 \mathrm{~mm}$. in the widest part, and $0.45 \mathrm{~mm}$. wide at base. 

Twigs somewhat curving, dark brown, pubescent at and near the tips but glabrous lower down; 3 to $4 \mathrm{~mm}$. In diameter in the center of terminal growth, $6 \mathrm{~mm}$. on wood of the year preceding; epidermis flaked to form rather large streaks of scarfskin; internodes 18 to 20 on each year's growth, averaging $23 \mathrm{~mm}$. 1ong, maximum length $35 \mathrm{~mm}$., minimum $8 \mathrm{~mm}$; lenticels many moderately conspicuous, scattered, oval, yellowish, raised, small. Terminal bud dark brown, very obtuse or truncate conic; the outermost pair of scales enclosing the tip; densely tomentose; $4.5 \mathrm{~mm}$. long, $3 \mathrm{~mm}$. Wide at base. Lateral buds free, much flattened, broad conic or cuneiform, acute pointed; medium in size, $3 \mathrm{~mm}$. long, 2.5 to $3 \mathrm{~mm}$. wide at base. Leaf-scars narrow arcuate with well marked central lobe; $3 \mathrm{~mm}$. broad, $0.5 \mathrm{~mm}$. high in the center; bundle scars absent, or occasionaliy present and inconspicuous.

\section{RHODE ISLAND.}

Synonyms: Burlington Greening, Greening, Green Newtown Pippin, Hampshire Greening, Jersey Greening, Rhode Island Greening, Verte de l'Ile de Rhodes, Verte de Rhode Island, Belle Dubois, Greening Rhode Island, Green's Inn, Greenling van Rhode Island, Russine. 3

Medium late variety originated in Rhode Island. 3

"Tree large or above medium, strong, vigorous. Form wide, spreading, somewhat drooping. "I

Leaves ovate, densely crowded alcng the shoot, medium in width, apex mostiy acute but sometimes acuminate, base cuneate, not cordate; the margin deeply and evenly biserrate, the 

prinary teeth rather obtusely pointed, and the secondary teeth shallow; sinuses deep, acute, and rather broad; completely glabrous above on the oldest leaves, with some tomentum still persisting on the midrib on younger terrinal leaves; nearly glabrous beneath, the pubescence limited to a few hairs along the midrib and principal veins on the most mature leaves; usually $8 \mathrm{~cm}$. long, $5.5 \mathrm{~cm}$. wide, frequently smaller, seldom much larger. Petiole with groove very narrow and shallow above, becoming broader toward the pulvinus; tomentose throughout, especially along the groove; $30 \mathrm{~mm}$. long, $2 \mathrm{~mm}$. in diameter. Stipules attached $2 \mathrm{~mm}$. from the base of the petiole, persisting on all leaves, linear lanceolate, acute, petiolate, the constricted portion ("petiole") about $1 / 3$ the total length; the margin undulate, and pointed with dark spine like glands; glabrous on the expanded portion above tomentose on the "petiole", tomentose along the margin and at the "petiole" but other wise glabrous beneath; $14 \mathrm{~mm}$. long, $0.87 \mathrm{~mm}$. In the widest part, $0.26 \mathrm{~mm}$. Wide at base.

Twigs very slightly curving, deep reddish brown or green, rather densely pubescent near the tips, but becoming less so lower down; $4 \mathrm{~mm}$. in diameter on the center of terminal growth, $5 \mathrm{~mm}$. cn growth of the year before; epidermis flaked to form long, narrow, streaks of gray scarfskin; internodes usually 10 to 15 on each year's growth; maximum length $40 \mathrm{~mm}$., average 25 to $30 \mathrm{~mm}$, minimum $12 \mathrm{~mm}$; lenticels many exceedingly conspicuous, scattered but most numerous at nodes, round, or more frequently, round oval, light straw-color, raised, medium to large in size. Terminal bud truncate conic, the two outermost 

scales reaching above the apex; dull gray; densely tomentose especially at the edges of scales, $5 \mathrm{~mm}$. Wide at base, $6 \mathrm{~mm}$. long. Lateral buds appressed in part in many cases, but frequently entirely free, although the apex never points outward; much flattened, broad rounded cune iform; large, $3 \mathrm{~mm}$. long, 3 mm. Wide, apex obtusely pointed, the margin of the scales fringed with hairs. Leaf-scars arcuate, the central lobe rather large, $1 \mathrm{~mm}$. wide, $1 \mathrm{~mm}$. high; bundle scars rather conspicuous.

\section{WILLOW.}

Synonyms: James River, Willow Leaf, Willow Twig. 1 and 3 Late variety, origin uncertain. ${ }^{1}$ Virginia? ${ }^{3}$

"Tree form upright spreading, with terminals drooping on bearing trees." I

Leaves elongated ovate or occasionally obovate, apex acute, base more or less cuneate; the margin serrulate, the teeth short-acute pointed and rather widely spaced; glabrous above except on the midrib near the petiole; sparsely hairy along the midrib and principal veins beneath; $8.5 \mathrm{~cm}$. long, 4 cm. wide. Petiole pubescent in the groove and along its edges above; glabrous beneath except at the pulvinus which is covered with short fine hairs; $40 \mathrm{~mm}$. long, $1 \mathrm{~mm}$. in diameter. Stipules lanceolate-linear, acute, the rargin edged with minute black spinelike glands and very slightly undulate; tomentose at base, glabrous on the upper portion above and beneath, except for a fringe of hairs along the margin, $8 \mathrm{~mm}$. long, 1.5 to $1.0 \mathrm{~mm}$. wide.

Twigs straight and drooping, light yellowish green, glabr- 

ous except on the terminal internode which is puberulent, 1.5 $\mathrm{mm}$. In diameter at the center of terminal growth, $2.5 \mathrm{~mm}$. and $4 \mathrm{~mm}$. respectively on wood of $/ \mathrm{two}$ years preceding; epidermis entire, i.e. with no scarfskin, no waxy bloom; internodes 6 to 8 on each year's growth, usually $7 ; 20$ to $30 \mathrm{~mm}$. long, averaging $25 \mathrm{~mm}$. and seldom shorter; lenticels not numerous, not conspicuous, scattered, elliptical, dark brown, raised, small. Terminal bud rather long conic, slightly flattened in one direction, apex somewhat truncate; the outermost pair of scales only $1 / 3$ as long as the bud; tomentose throughout except on the outer pair of scales which are hairy on the upper third but nearly glabrous and glossy green below; length of bud $7 \mathrm{~mm} ., 4$ $\mathrm{mm}$. In the widest part, $3 \mathrm{~mm}$. Wide at base. Lateral buds small, broad, much flattened conic, acute pointed; tightly appressed; sparsely torentose throughout, more especially so at the tip; 1.5 to $2 \mathrm{~mm}$. wide at base, $1.5 \mathrm{~mm}$. long. Leaf-scars slightly projecting outward, crescent shaped and distinctly three lobed; $3 \mathrm{~mm}$. broad, $0.5 \mathrm{mr}$. in the widest part; bundle scars when present small, usually indistinct or wanting, seldom conspicuous.

\section{WINESAP.}

Synonyms: Holland's Red Winter, Royal Red of Kentucky, Texan Red, Wine Sap, Wine Sop. ${ }^{1}$ Pot Pie Apple, Winter Wine Sap. 3 Very late variety originated in New Jersey. 3 "Tree medium size, vigorous. Form roundish spreading, rather straggling and open." I

Leaves mostly lanceolate-ovate but occasionally broader, apex abruptly acuminate or acute, base cuneate; margin serrate 

or biserrate, the teeth rather broader than deep, with roundish blunt points curving well forward; sinuscs acute; at maturity completely glabrous above, or at most, only a few hairs on the midrib near the petiole on terminal leaves, glands very few in number, inconspicuous, most abundant on the lower half of the leaf-surface and along the principal veins; sparsely tomentose beneath on the ends of twigs, glabrate lower down; $6.5 \mathrm{~cm}$. Iong, $3 \mathrm{~cm}$. wide, and frequently smaller. Petiole with narrow shallow and inconspicuous groove; tomentose in the groove and along its edges, very sparsely hairy to glabrescent beneath; densely pubescent on all sides at the pulvinus which is tinged with deep red. Stipules not often found on fully developed narrow leaves, but rather abundant on the smaller broader leaves especially on those on late twig growths; linear acicular, acuminate, constricted slightly for $1 / 3$ the length to become somewhat petiolais, the margin slightly undulate with vestiges of a few spiny teeth; glabrous above, pubescent beneath; $7.5 \mathrm{~mm}$. to $10 \mathrm{~mm}$. Iong when fully developed, $0.51 \mathrm{~mm}$. in the widest part, $0.34 \mathrm{~mm}$. wide at base.

Twigs very slightly curving, dark brown, heavily pubescent on the last season's growth, but becoming glabrous lower down; $2 \mathrm{~mm}$. in diameter at the center of terminal growth, $5 \mathrm{~mm}$. in diameter on wood of the year preceding; epidermis flaked to produce a thin gray scarfskin; intornodes 10 to 12 on each year's: growth; 15 to $25 \mathrm{~mm}$. long; lenticels many, very evident, especially clustered below the nodes, oval, yellow, slightly raised, above medium in size. Terminal bud dark brown, oval, blunt pointed, the two outermost scales reaching nearly to the apex; 

densely tomentose; $5 \mathrm{~mm}$. Iong, $4 \mathrm{~mm}$. broad. Lateral buds large, broad, obtusely conical, most often nearly free but frequently appressed; $4.5 \mathrm{~mm}$. Iong, $3 \mathrm{~mm}$. broad. Ieaf-scars curved, very narrow, $3.5 \mathrm{~mm}$. broad, $0.5 \mathrm{~mm}$. high in the center; bundle scars not evident.

\section{TYTHE.}

Synonyms: Illinois Pippin. 3

Late variety originated in IIlinois. 3 Not listed. ${ }^{1}$

Leaves rather broad, ovate, apex acuminate, base cuneate; two or three times serrate, primary teeth sharp pointed; sinuses deep acute, especially evident near the apex; glabrous above except for a slight tomentum on the lower portion of the midrib; glabrescent beneath but with a few hairs persisting on the midrib and veins, $6.5 \mathrm{~cm}$. Iong, $4.2 \mathrm{~cm}$. wide, to $7 \mathrm{~cm}$. by $4 \mathrm{~cm}$. Petiole pubescent throughout; $22 \mathrm{~mm}$. Iong, $1.5 \mathrm{~mm}$. in diameter. Stipules lanceolate, very short cetiolate, that is, constricted for about $2 \mathrm{~mm}$. at the base; sinuately dentate, each tooth tipped with a small dark spine-iike gland; glabrous above, pubescent on the lower half and on the margin especially beneath; 8 to $15 \mathrm{~mm}$. 1ong, 2 to $1.7 \mathrm{~mm}$. in the widest part, 0.26 mm. wide at base.

Twigs rather slender, strongly upward-curving, dark green, pubescent on wood two years old and younger, becoming completely glabrous lower down; $2.5 \mathrm{~mm}$. in diameter at the center of terminal growth, $3.5 \mathrm{~mm}$. on four year old wood; epidermis unbroken, patches of white waxy deposit on the older portion especially, but appearing throughout in sheltered places; internodes 5 to 6 on each year's growth, 5 to $10 \mathrm{~mm}$. Iong on 

terminals, 20 to $25 \mathrm{~mm}$. lower down; lenticels numerous, conspicuous, scattered, oval, yellowish brown, not raised, medium to large. Terminal bud elongated oval, blunt pointed; the two outer scales half free and extending only half way to the tip; glabrous except for a tomenturn on the tip; light green on the glabrous portion; dark brown above, the inner scales light green and Elabrescent except for a dense tomenturn at tips and margin; $8 \mathrm{~mm}$. long, $4 \mathrm{~mm}$. wide at base* Lateral buds very obtuse conic, rounded at tip on lower portion of the shoot, but larger and more acute-pointed on the upper part; scales glabrous, glossy light green throughout on lower buds, the upper portion blackened on the larger upper buds; appressed; the larger buds $2 \mathrm{~mm}$. wide at base and $3 \mathrm{~mm}$. long, the smaller $2 \mathrm{~mm}$. wide at base and $1.5 \mathrm{~mm}$. long. Leaf-scars narrow, straight or very slightly curving; $2 \mathrm{~mm}$. broad, about $0.2 \mathrm{~mm}$. high; bundle scars present but very inconspicuous.

\section{YELLOW TRAISPARENT .}

Synoyms: De Revel, Grand Sultan, Revelstone, Skwosnoi Schotoi, Transparente de St. Leger, Transparente Jeune. ${ }^{2}$

Extra early Russian variety imported by the United States Department of Agriculture in 1870.2

"Tree medium size, moderately vigorous, with short stout crooked branches filled with short spurs. Form upright at

*Tatersprouts (collected December 8th, 1915) densely tomentose on the upper half, becoming less so farther down and finally glabrescent to glabrous at the base; the terminal bud acute and densely torentose; lateral buds tomentose on the hairy portion of the twig. 

first but becoming spreading or roundish and rather dense. 12 Leaves ovate, apex acuminate the tip $8 \mathrm{~mm}$. broad and $7 \mathrm{~mm}$. long, base round or slightly cordate; the margin serrulate; sinuses very acute; slightly pubescent on the midrib but otherWise glabrous above; rather sparsely tomentose beneath; $9 \mathrm{~cm}$. long, $6 \mathrm{~cm}$. wide. Petiole curving, rather slender, the groove well marked; tomentose throughout but especially so at the pulvinus; $30 \mathrm{~mm}$. long, $1.5 \mathrm{~mm}$. in diameter. Stipules ranting, or vestigial and under $2 \mathrm{~mm}$. long.

Twigs curving slightly upward, rather light greenish brown; puberulent; $2.5 \mathrm{~mm}$. at tips, $5 \mathrm{~mm}$. in diameter at the base; epidermis slightly flaked to form a small amount of scarfskin; Internodes 5 or 6 on each year's growth, normally about $20 \mathrm{~mm}$. long; lenticels many, oval or long elliptical, not raised, small to below medium. Terminal bud yellow brown, roundish conic, pubescent; $6 \mathrm{~mm}$. long, $4 \mathrm{~mm}$. Wide at base. Lateral buds free, obtuse, plump, slightly hairy; $1.5 \mathrm{~mm}$. broad, $1 \mathrm{~mm}$. Iong. Leaf scars curved, narrow, crescent shaped, $3 \mathrm{~mm}$. wide, $1 \mathrm{~mm}$. high; bundle scars prominent. 

IV.

Bibliography.

1. Beach, S. A., The Apples of New York, Vol. I.

2. Beach, S. A., The Apples of New York, Vol. II; published by the New York (State) Agricultural Experiment Station, Geneva, as Part II of the Annual Report for 1903. 1905.

3. Ragan, W. H., Nomenclature of the Apple, United States Department of Agriculture, Bureau of Plant Industry, Bulletin No. 55. 1908.

4. Shaw, J. K., The Technical Description of Apples, Massachusetts Agricultural Experiment Station, Bulletin No. 159. December, 1914.

5. De Candolie, A. P., Vegetable Organography, Translated by Boughton Kingdon. Ed.? Vol. I, page 283. 1841.

6. Sinnott, E. W., and Bailey, I. W., Investigations on the Phylogeny of the Angiosperms. 3. Nodal Anatomy and the Morphology of Stipules. American Journal of Botany, Vol. I, No. 9. November, 1914.

7. Waugh, F. A., Systematic Pomology, Orange, Judd Company New York, 1903.

8. Bailey, L. H., and Miller, W., Cyclopedia of American Horticulture, New York, The Macmilian Co. 1900.

9. Schneider, C. K., IIIustriertes Handbuch der Laubholzkunde, Jena, Verlag von Gustav Fischer, 1906.

10. Schneider, C. K., Dendrologische Minterstudien. Verlag von Gustav Fischer in Jena, 1903.

11. Britton, N. I., North American Trees. New York, Henry Holt and Company, $190 \overline{8}$. 

ALPHABETICAL INDEX.

page

Bibliography - - - - - - - - - - - 41

Description of Varieties - - - - - - - - 9

Introduction _. - . . . . . . . . 2

Key $\quad-\ldots-\ldots-\ldots$

Table of Contents - - - - - - - - - - 1

Varieties Treated _ . . . . . . . . . . 9

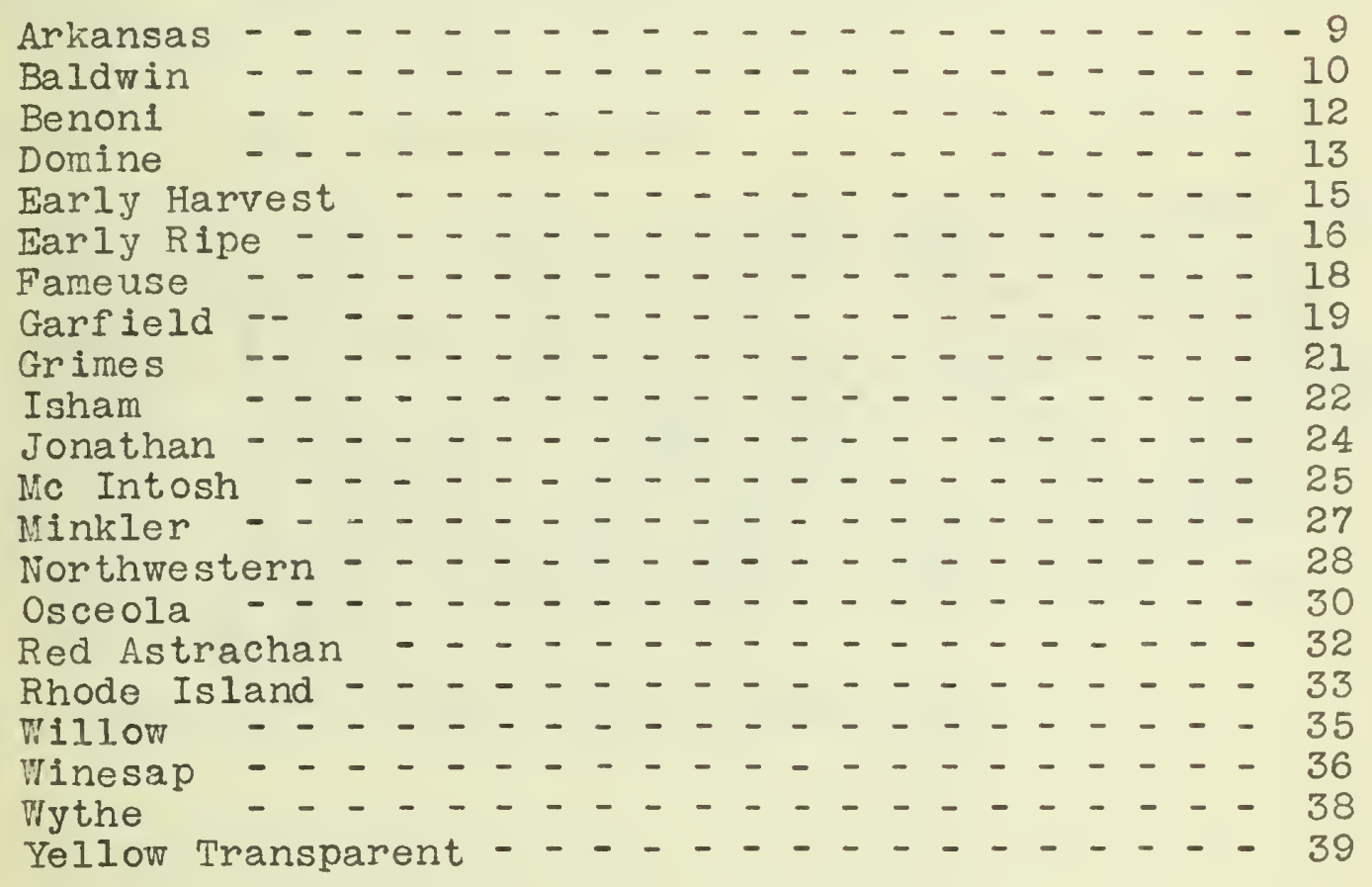



Explanation of Plate $I$.

A. Stipules of some early varieties.

Reading from left to right: 1 Early Harvest, upper surface. 2. Early Harvest, lower surface. 3 Fameuse, upper surface. 4 Fameuse, lower surface. 5 Red Astrachan, upper surface. 6 Red Astrachan, lower surface. 7 Oldenburg, upper surface. 8 Oldenburg, lower surface. 9 Yellow Transparent. 10 Red June, upper surface, 11 Red June, lower surface.

B. Stipules of some late varieties.

Reading from left to right; top row: I Baldwin, upper surface. 2 Baldwin, lower surface. 3 Domine, upper surface. 4 Domine, lower surface. 5 Garf1eld, upper surface. 6 Grimes, upper surface. 7 Grimes, lower surface. 8 Jonathan, of extreme (aberrant) size. 9 Jonathan, upper surface. 10 Jonathan, lower surface. Bottom row: 11 Isham, upper surface. 12 Isham, lower surface. $13 \mathrm{Mc}$ Intosh, upper surface. $14 \mathrm{Mc}$ Intosh, lower surface. $15 \mathrm{MinkIer,} \mathrm{lower} \mathrm{surface.} \mathrm{I6} \mathrm{Northwestern,}$ upper surface. 17 Nolthwestern, Iower surface. 18 Rhode Island, upper surface. I8 Rhode Island, lower surface. 20 Rhode Island. (lanceolate-Iinear type).

All magnified to three times natural size. 



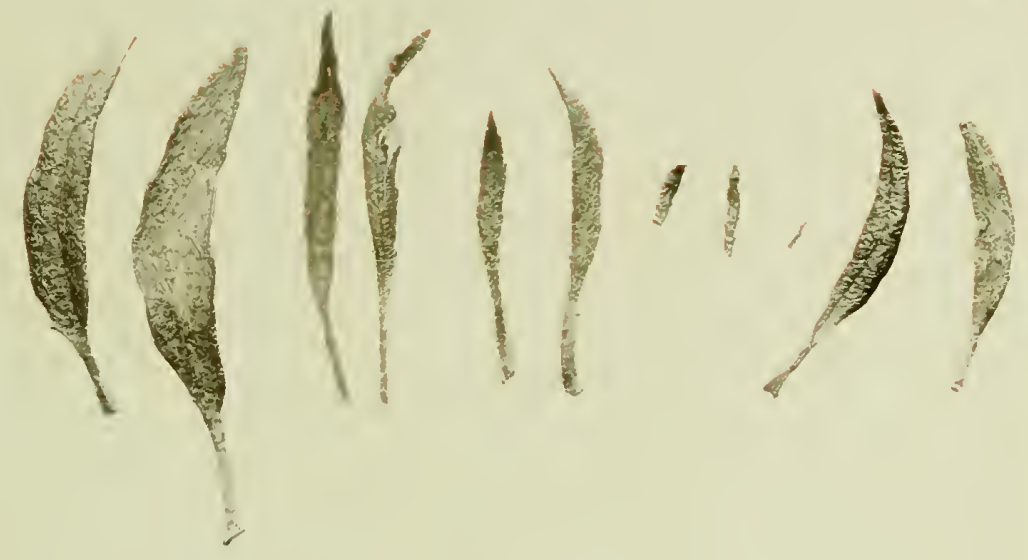

A. Stipules of some early varieties.
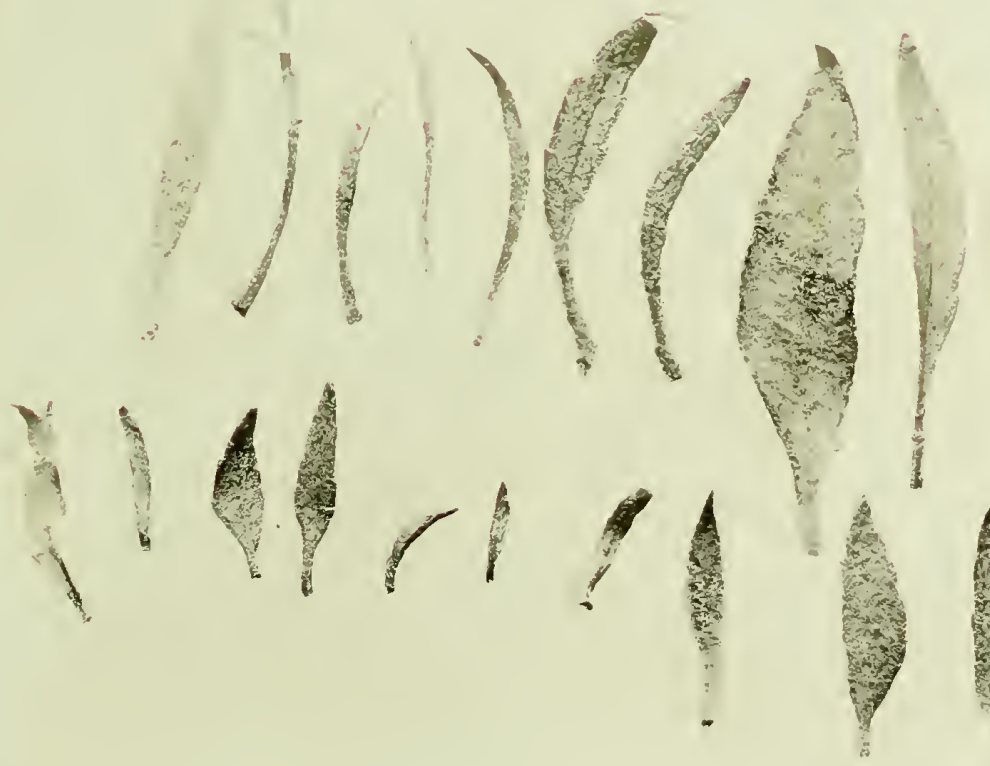

B. Stipules of some late varieties. 


